\title{
$O$ verbo contra o verme: \\ violência simbólica, liderança intelectual e guerra em Agostinho Neto e Noêmia de Sousa
}

\author{
Maria Nilda Carvalho Mota ${ }^{1}$
}

RESUMO: O ensaio aproxima os poemas Bayete, da moçambicana Noêmia de Sousa, e Depressa, do angolano Agostinho Neto, analisando e discutindo questões relativas à violência simbólica, liderança intelectual e guerra de libertação em ambos os autores e respectivos contextos.

ABSTRACT: The essay approaches the poems Bayete, by Mozambican Noemia de Sousa, and Depressa, by Angolan Agostinho Neto, analyzing and discussing issues of symbolic violence, intellectual leadership and war of liberation in both authors and contexts.

PALAVRAS-CHAVE: Poesia engajada; Liderança intelectual; Violência simbólica; Guerra; Angola e Moçambique.

KEYWORDS: Engaged Poetry ; Intellectual leadership; Symbolic violence; War; Angola and Mozambique.

Representantes de um tipo de poética engajada, de um lirismo que se poderia "bandeiramente" chamar de "hostil" a tudo o que não fosse libertação, Noêmia de Sousa e Agostinho Neto foram exemplos de grandes artistas e intelectuais do século XX.

Este pequeno ensaio procura estabelecer uma comparação entre os poemas Depressa, de Agostinho Neto e Bayete, de Noêmia de Sousa, atentando para o fato de que, apesar de serem textos bastante

\footnotetext{
${ }^{1}$ Mestranda USP; Título do projeto de mestrado: Lirismo de libertação - Análise comparativa de poemas de Agostinho Neto, Noêmia de Sousa, Landê Onawale e grupo Clã Nordestino. Contato: duppr@ig.com.br
} 
distintos, ambos foram escritos em períodos de "gestação bélica"2. O foco deverá repousar sobre o modo pelo qual essas situações de guerras prementes foram incorporadas aos textos, a questão da liderança intelectual dos autores e o combate à violência simbólica, buscando, na medida do possivel, salvaguardar suas particularidades de tempo, espaço, estratégias políticas e poéticas.

É de conhecimento comum que escrita e resistência, estética e ética, andam juntos na literatura, uma vez que "no fazer-se concreto e multiplamente determinado da existência pessoal, fios subterrâneos poderosos amarram as pulsões e os signos" e, mais que um acaso de combinações, essa interação, entre desejos e imagens, garante a vitalidade das esferas artística e teórica. (BOSI, 2002, p. 119)

No mundo real - este que serve de apoio à literatura, sendo o referente sem o qual não a compreenderiamos - existe um tipo de violência que está posta em todos os lugares onde existam relações de poder. Trata-se da "violência simbólica" característica das relações de dominação onde não se pressupõe a coerção física, sendo, antes, "uma forma irreconhecível, transfigurada, e legitimada, das outras formas de poder" (Bourdieu, 2000, p. 15).

A título de exemplo, pensemos numa situação colonial - já que os poemas escolhidos, de ambos os autores, foram escritos quando seus países passavam por esse período histórico, ambos sob dominação portuguesa. Quando, genérica e hipoteticamente falando, um trabalhador chega em sua casa e a encontra destruída pela chuva, este trabalhador (que é legalmente explorado), via de regra, não terá tempo, nem ânimo de lamentar sua sorte, pois será preciso, com urgência, lavar, secar e buscar locais secos para descansar e trabalhar no dia seguinte. Neste mesmo dia seguinte, entretanto, o trabalhador terá a oportunidade de verificar que, "milagrosamente", a enchente vilã não atingiu o seu patrão, pois sua casa fica localizada em local seguro e

2 Antes da formalização das guerras de libertação que se efetivaram em 1974, no caso de Moçambique e 1975, no caso de Angola. 
protegido dos ciclos da natureza, só chegando mesmo a ser atingida nas raras situações de catástrofes naturais.

De um modo geral, e apoiado na teoria da violência simbólica de Bourdieu, pode-se afirmar que existe, por parte do mais fraco (na escala social), a necessidade de esquecer que está sendo cotidianamente enganado, roubado, violentado ou oprimido, tanto nas situações trágicas, como no exemplo acima, quanto nas mínimas relações cotidianas, pois, de modo contrário, ou esse saber paralisaria esse sujeito vitimizado, ou o faria voltar os olhos e armas contra os agentes destas violências. A consciência, nesse caso, é, tal qual na gênese cristã, um fruto proibido, que traz a ciência, mas expõe também a nudez, as "vergonhas", de cada um.

É enquanto intelectual de seu tempo, detentora de um saber que se espera maior do que o senso comum, que Noêmia de Sousa, no poema Bayete (que significa uma espécie de saudação real, no idioma ronga), expõe algumas dessas "vergonhas". Nos 13 versos da primeira estrofe, são desfiladas 13 situações que, se não combatidas, tornam-se motivos de envergonhamento, mas que, quando combatidas, podem ser componentes de uma bandeira de guerra.

O primeiro motivo é a imposição da religião ocidental, pois a religiosidade africana foi, durante o periodo colonial e após, tratada simplesmente como demoníaca e, portanto, maléfica. Mesmo o que pôde resistir à opressão branca e vazou para os outros continentes junto com os navios negreiros e sobrevive até hoje na América Latina (o vodum, em Cuba, e o candomblé, no Brasil) são, cotidianamente, tratados como casos de polícia. Não é raro a polícia interromper rituais de candomblé, especialmente nas periferias das grandes cidades, sob a alegação de perturbação da ordem.

O segundo motivo é o comércio desfavorável à colônia. A relação importação/exportação e exploração tão característica dos processos coloniais: "Vendeste-me o algodão da minha machamba/ pelo dobro do preço por que mo compraste" (SOUSA, 1988). 
O terceiro motivo é a legislação desfavorável aos colonizados. Todo o código civil dos territórios ultramarinos portugueses era feito para proteger os colonos e explorar os colonizados e, assim como o código civil, também o código de ética, fora traçado pelo colonizador branco, sendo este o quarto motivo de rebeldia no poema.

O quinto, o sexto e o sétimo motivos estão relacionados: a construção de cadeias, a imposição dos impostos e o aprisionamento do povo, respectivamente, revelam a angústia visceral em que vivem os nativos e os colonos, pois, estes últimos, sendo, à força, os donos dos patrimônios existentes, necessitam enxergar todo o resto, os colonizados "despossuídos", como constantes ameaças ao seu poder. É preciso construir cadeias e pregar o horror, doutrinar com uma religião que ensine a oferecer a outra face ao inimigo. Como os colonizados são vistos como perigosos, a violência simbólica, apenas, não basta para manter o controle e prevenir rebeliões. É preciso violentar, aterrorizar, doutrinar, mandar prender e matar - na tentativa de evitar que as mesmas violências retornem ao ponto de partida.

A negligência, a exploração do trabalho, a fome, a falta de solidariedade e humanidade do colonizador são os motivos de número oito, nove, dez e onze, expressos no poema. A prostituição das mulheres e a sua deportação para S. Tomé, por sua vez, são os últimos motivos listados nesta estrofe.

Para além da "listagem" de motivos para uma luta a favor da libertação, chama a atenção neste poema o modo como Noêmia transforma a forma poética e figuras de linguagem, em armas de guerra. Nesses dezessete versos vemos um tom prosaico, de sonoridade próxima à prosa, sem rimas e com versos livres (talvez para que nem mesmo os sons, ou a métrica, possam ser aprisionadores), construidos sob um tom irônico, muito mais trágico do que cômico. E contra a ironia, não pode haver argumentos, geralmente não há escudos.

Como vemos, é um poema muito didático, pois expõe uma série de razões para dar adeus, para não reverenciar (bayete) a 
Portugal, para que as razões de vergonha, uma vez expostas, passem a ser motivos de luta.

Essa necessidade de o sujeito poético dizer o que, em tese, não seria necessário, já que a realidade está posta e o sofrimento da pessoa em situação de colonização nunca foi nenhum segredo, ao menos para os que por ele foram vitimizados, é importante porque, dentre outras coisas, violência e poder simbólico, para serem exercidos, necessitam da cumplicidade das pessoas que os sofrem, sem desejar saber que lhes estão sujeitos. Ou seja, o poder precisa ser reconhecido como legítimo e sua violência implícita tem, necessariamente, que ser ignorada (BOURDIEU, p. 14).

Mas aos intelectuais como Noêmia e Agostinho Neto, no entanto, não lhes foi dado o direito de ignorar violências sofridas ou cometidas, especialmente aquelas que vão contra os mais fracos. Talvez por isso os intelectuais tenham tido quase sempre um papel de destaque nas insurreições de todo o mundo. Não houve nenhuma revolução na história moderna sem intelectuais e, de modo inverso, também não parece ter havido nenhum grande movimento contrarevolucionário sem eles (SAID, 2005, p. 25).

Embora as discussões de Edward Said tenham origem na definição do intelectual de Gramsci, no seu modo de ver, esses seres não se resumem a profissionais competentes, defensores das classes abastadas - mas, antes, alguém cuja função seria representar a todas as pessoas e problemas que, comumente, respousam sob as neblinas da conveniência e, de um modo geral, para Said, isso significa tomar partido dos mais fracos.

No poema Depressa, de Agostinho Neto, é o Verbo poderoso, capaz de criar e destruir, presente tanto na teogonia ocidental quanto nas tradições bantu, quem demonstra, na prática do poema, a estratégia e posição política do autor, na relação forma-conteúdo.

A sintaxe deste poema, por desejar a ação concreta, libertadora, não pode permitir sujeitos e vozes passivas. Por isso, o sujeito poético esforça-se por mobilizar outros sujeitos em direção ao 
campo de batalha, retirando, inclusive, a pontuação dos versos, como se retirasse os obstáculos para que:

Inicie-se a ação vigorosa máscula inteligente que responda dente por dente olho por olho homem por homem venha a ação vigorosa do exército popular pela libertação dos homens venham os furacões romper esta passividade

(NETO, 1985)

A violência, que é característica dos momentos de guerra, é descrita ao longo de estrofes em que versos dinâmicos representam a transformação de florestas em territórios de luta, campos de batalha com cenário característico (sangue e vísceras espalhadas): "para que a maldade de suas vísceras / fique para sempre aí plantada" (NETO).

Com a colocação do advérbio "depressa", estrategicamente, ao alto, no título do poema, este último transmuta-se em um grande verbo capaz de modificar a realidade. O poeta logra criar um "Grande Verbo" (o próprio poema) que representará o povo contra os "grandes vermes" coloniais. Essa transmutação é reforçada pela presença, na composição, de muitos outros pequenos verbos indicando ações transformadoras: acabemos, inicie-se, soltem-se, vibrem, venham, esmaguem, vindimem, esborrache, atraia-se, rompa, não esperemos, escorracemos etc. Todos verbos característicos de atitudes violentas, cujo imperativo reforça o tom de urgência transformadora. São atitudes de rompimento, de coragem, força e iniciativa, mas que não podem ser confundidas com a violência simbólica - uma vez que não são dirigidas do mais forte para o mais fraco e, principalmente, boa parte desses verbos pressupõe coerção física.

Todos eles, coroados com o "Depressa" no alto do texto, compõem, como disse, o grande e urgente verbo da libertação. Depressa, que a liberdade não pode esperar. Depressa, que os justos estão morrendo. Depressa, que as cadeias estão cheias. É a voz do sujeito poético desejando-se voz de um sujeito coletivo e ativo. É 
também a voz do poeta, intelectual e futuro guerrilheiro, tentando cumprir o seu papel com a nação em formação, preparando os sujeitos para a guerra inevitável, incorporando os seu indícios, os seus embriões.

Já na primeira estrofe, os cinco verbos no presente do indicativo, com predominância da voz passiva e, logo em seguida, na segunda estrofe, o uso do imperativo, indicam um futuro que não pode mais esperar para acontecer. O papel de liderança intelectual fica aí expresso desde o início do poema.

A passividade geral, da qual o sujeito poético, em deliberado uso da voz ativa em primeira pessoa do singular, faz questão de não compartilhar, mas antes de afastar para longe, é expressa na voz passiva pois cumpre bem a função de descrever a "mornez" alheia - esta calma precisa ser combatida, pois o poema sugere que é a passividade dessas vozes quem permite o assassinato dos jovens, dos justos, e os coloca à mercê das cadeias, contra o muro da violência colonial.

Ocorre que os verbos, com seu poder diminuído, passam a ser permissivos quando deixam as coisas acontecerem per si. É como se esta permissividade alheia, expressa pelo uso da voz passiva, caracterizasse a cumplicidade necessária para a ação violenta do dominador, tanto no campo simbólico quanto na prisão e assassinato dos jovens. É como se estas vozes passivas permitissem que toda a opressão fosse continuada.

Com excessão da primeira estrofe, iniciada na primeira pessoa do singular, como que a reforçar o desejo de liderança de um sujeito poético impaciente, e da quinta estrofe, onde quem simbolicamente "impera" é um nome, acompanhado de um adjetivo (“África gloriosa”), é no imperativo que os verbos abrem todas as outras estrofes, buscando romper esta "mornez histórica" e fazendo soar no poema o desejo do sujeito poético: a libertação de seu povo.

Noêmia que, por seu turno, também transformou o poema em campo de batalha, o fez com uma estratégia distinta, expondo, em poucos versos, muitos motivos para a guerra e delimitando os inimigos: 
nos dezessete versos das duas estrofes somadas, aparecem quinze motivos de luta e duas bandeiras opostas: a capulana vermelha e verde, de Portugal, e a bandeira de libertação moçambicana.

São duas bandeiras opostas, em duas estrofes que se complementam. A primeira ergue a lança, prepara o gatilho, expõe todos os motivos que movem a luta em direção ao "verme". A segunda, ataca. Em vez de saudar, dá adeus ao cabresto-capulana-vermelha-everde.

Assim, o destaque no poema de Noêmia parece repousar sobre a descrição dos motivos para a guerra, na ironia, transformada em armamento bélico e na busca de liberdade, através da liberdade métrica, da ausência de rimas e da controvérsia entre a forma (poema) e o tom (de prosa), enquanto que em Agostinho Neto, repousa, principalmente, sobre a ostensiva incitação à guerra, através do uso de muitos verbos no imperativo. Se fossem poemas de um mesmo país, talvez poderiamos dizer que ambos se complementam, na medida em que o primeiro apresenta um cenário de violência física e simbólica, contribuindo para desfazer a cumplicidade e ignorância necessárias para a luta, enquanto que "Depressa" propõe a reviravolta, a ofensiva, o "olho por olho".

Por fim, quanto à liderança intelectual - essa capacidade de estar na linha de frente também no caso de as batalhas serem travadas no campo das ideias - verifica-se que ambos não fogem à responsabilidade, antes, a puxam para si, desejam falar em nome de seu povo e, como atesta Agostinho Neto - que foi guerrilheiro, antes de ser presidente da nova república - sua vida, como a de Noêmia, não desmente os seus poemas. 


\section{Referências bibliográficas}

BOSI, Alfredo. Literatura e resistência. São Paulo: Companhia das Letras, 2002.

BOURDIEU, Pierre O poder simbólico. Trad. Fernando Tomaz. 3. ed. Rio de Janeiro: Bertrand Brasil, 2000.

NETO, Agostinho. Sagrada esperança. São Paulo: Editora Ática, 1985. (Col. Autores Africanos.)

SAID, Edward W. Representações do intelectual: As Conferências Reith de 1993. Trad. Milton Hatoum. São Paulo: Companhia das Letras, 2005.

SOUSA, Noémia de. Sangue negro. Maputo :AEMO, 1988. 